\title{
THE BICYCLE AS A REAL FEEDER TO THE TRANSMILENIO SYSTEM IN BOGOTA AND SOACHA
}

\author{
C. MORENO ${ }^{1} \&$ C. MIRALLES-GUASCH ${ }^{2,3}$ \\ ${ }^{1}$ Piloto University, Colombia. \\ ${ }^{2}$ Department of Geography, Universidad Autónoma de Barcelona, Spain. \\ ${ }^{3}$ Institute for Environmental Science and Technology - ICTA, Universidad Autónoma de Barcelona, Spain.
}

\begin{abstract}
The main objective of this article is to illustrate the importance that TransMilenio and cycling have had on the inhabitants living in the periphery of Bogota and Soacha, based on surveys conducted among residents. Even though there is no legally confirmed Metropolitan Area between Bogotá and Soacha, there does exist a real conurbation, which has led to a relationship of economic dependence between the conurbated municipality of Soacha and the main city of Bogotá, and one aspect of this is daily mobility. The question is then, has Bogotá's Bus Rapid Transport - TransMilenio - been an integrating agent and has it improved access to and from this Megaproject of Ciudad Verde?

Keywords: accessibility, bicycle sharing system, Bogota, Ciudad Verde, cycling, daily mobility, public transport, Soacha, TransMilenio, travel time.
\end{abstract}

\section{INTRODUCTION}

Daily commute has a direct relation to poverty; the poorer the people, the bigger the problems and difficulties they have when commuting. This is mainly because of bad quality and limited supply of efficient and rapid public transport [1], making their daily travels longer and in many cases having to incur additional costs [2]. In many of these peripheral areas, residents experience difficulties in finding economic and efficient means of transport since many access roads are in a high degree of deterioration and in many cases the access roads are not suitable for vehicles.

Bogotá's Bus Rapid Transport (BRT) - TransMilenio - is widely known. It is a public transport system based on high-capacity buses segregated from private traffic. The TransMilenio was planned with the purpose of improving the quality and security of the public transport system, and allowed in practice a reduction in travel time and an increase in accessibility to all inhabitants of the city, especially the residents of low-income households. However, the impact of the TransMilenio on residents in peripheral communities has not been entirely positive [3].

This work looks at the importance of considering how daily mobility and public transport systems can become, what Garretón [4] calls, a fundamental factor of social integration and a multiplier of inequalities. Some of the results will focus on the advances and results of how daily mobility has become an important factor regarding opportunity access and the determination of quality of life, in this case among the population of the city of Bogota living on the peripheral areas.

This paper is part of the proceedings of the 10th International Conference on Urban

Regeneration and Sustainability (Sustainable City 2015)

www.witconferences.com 


\section{THE ECONOMIC AND DEMOGRAPHIC GROWTH OF BOGOTA AND ITS COMMUTING TIMES}

In almost all the cities of the world, thanks to transport policies that have favoured private transport to the detriment of public transport and non-motorized transport, the most vulnerable citizens are those who feel more marginalized with regard to transportation. These citizens have become what Vittadini calls the new prisoners of the modern city [5]. Likewise, a large number of households depend on public transport, but, due to vast social inequalities in big cities, especially in Latin America, this becomes a significant barrier to accomplishing sustainable development [6].

The metropolitan segregated structure, as called by Jirón et al. [7], was more accentuated in Bogotá between 1940 and 1970, when the traditional historical centre began to be abandoned by high-income households in search of places located north of the city. On the other hand, the south began to take on working-class characteristics, while the new industry was localized in the west, near the Train Station [8]. This form of city growth continued in the following decades; high-income families continued progressive displacement towards the north, while the poorest families continue moving away towards the south [1].

After the 1970s, the process of demographic growth and the reduction in intensity of migratory flows became a constant and the frontier of urbanization exceeded the boundaries of the city, thus generating a new model of metropolitan development [1] in which, as previously mentioned, the north became characterized by the wealthy classes and the south by the working classes. As highlighted by Cortés [9], Soacha became an important receptor of the city's underclasses who no longer inhabit the city itself, but rather settle outside of the city boundaries. This disordered city growth brought informal and illegal settlements in the periphery due to, among other factors, an absence of integrated planning, making these outlying territories places of residence and accentuating the city's social and economic precariousness.

The municipality of Soacha has an additional particularity in the sense that it experiences added demographic pressure due to internal forced displacement. This is because the majority of displaced people settle in the peripheral areas which, because of their proximity to Bogotá, become very attractive for new residents. However, these peripheral areas also tend to be zones of high risk or of a high environmental importance, leading to increased urban problems.

In the municipality of Soacha, employment and housing imbalances are evident since, according to mobility surveys [10], people living in Soacha and working in Bogotá, and also people living in the South periphery, spend too much time commuting, especially workers whose working contract is precarious (understood as informal or less than adequate remuneration for their work performed). Time spent commuting thus contributes to the creation of new expanded and segregated territories [11].

In Fig. 1 people using TransMilenio are taking more time for their daily travels. According to data from the Mobility Survey (EMU 2011 [10]), the bicycle would be the most efficient mode of transport in terms of time spent, since people who use bicycles take less time to reach their working places, without taking into account the socio-economic strata. Could we then think that the bicycle is a fair and equal means of transport? According to Avellaneda [2], poverty also affects travel time, since this variable depends largely on factors such as distance between residence and place of work, as well as the mode of transport used.

In Fig. 2, we can see that walking is the most used mode of transport in Bogotá in low and medium socio-economic strata (54\% and $37 \%$, respectively), followed by public transport with $23 \%$ in low strata and $20 \%$ in medium strata. On the other hand, in high strata, $47 \%$ of households use private car for travel and only $9 \%$ use public transport. Despite the fact that 


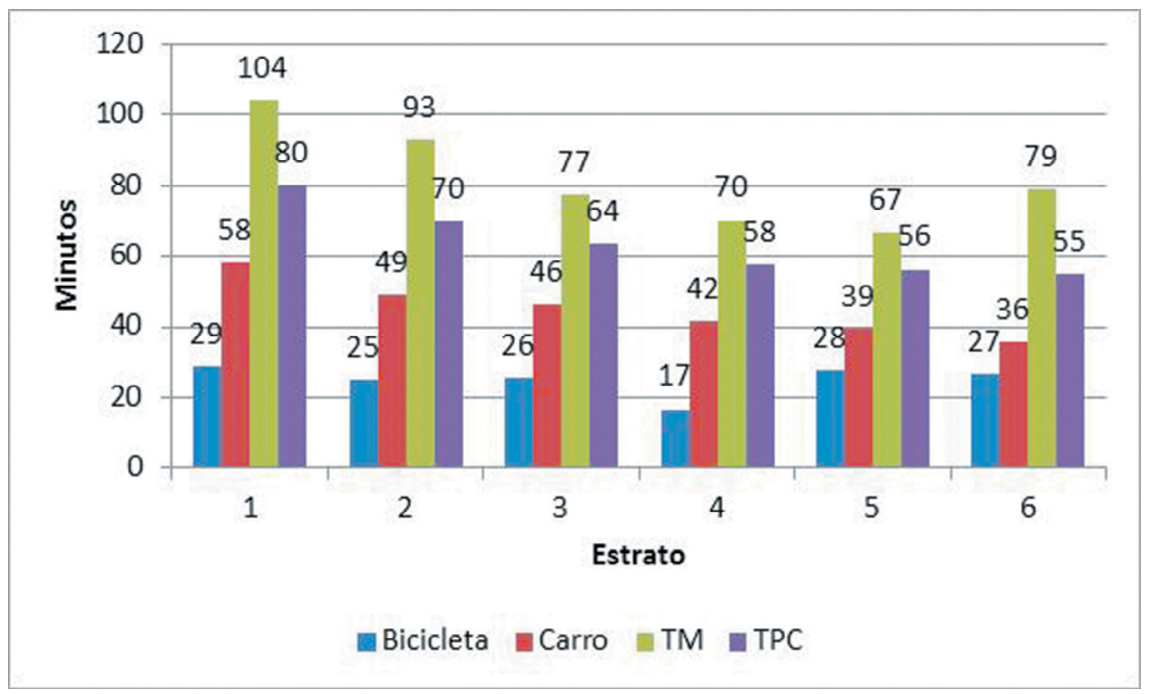

Figure 1: Commute time in minutes by socio-economic strata in Bogota (EMU 2011 [10]).

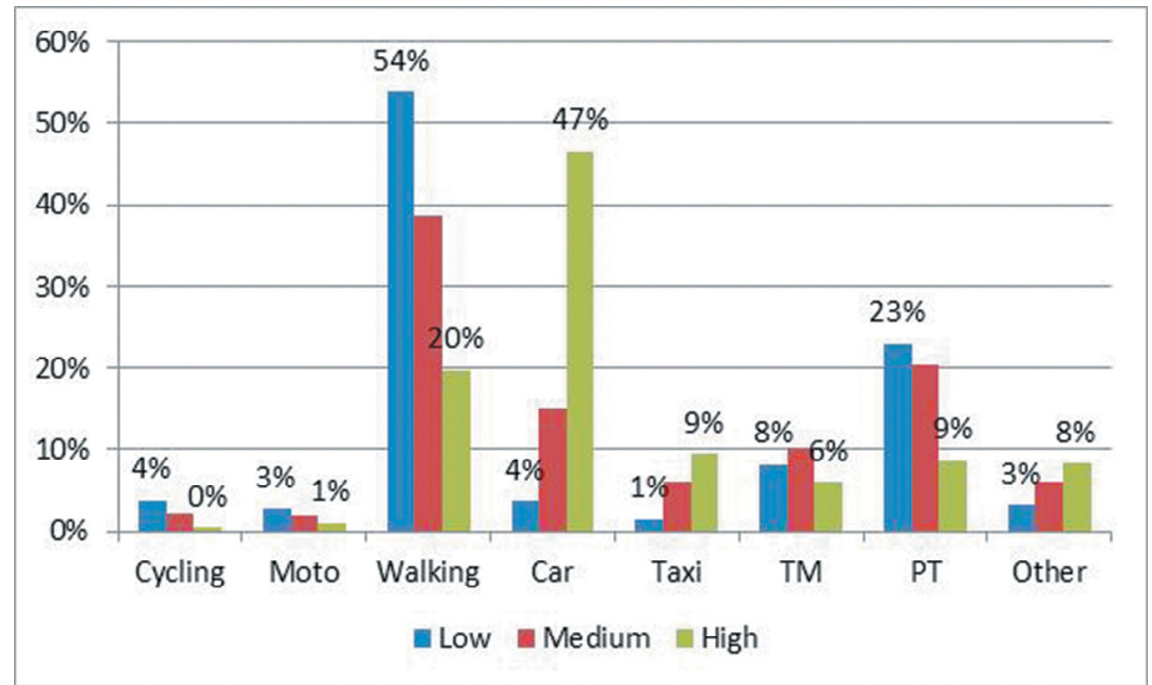

Figure 2: Transport means according to income levels in households of Bogota (EMU 2011 [10]).

past administrations have not promoted the use of public transport, its use has been growing but not in the desired proportion. The current administration will soon inaugurate some bicycle lanes in some city zones promoting their use so that cycling's modal share continues to grow.

Ultimately, it should be noted that in the metropolitan area between Bogotá and Soacha some imbalances are observed especially with reference to employment and residence because inhabitants living in the periphery require longer time to travel, as mentioned by Hurtado et al. [12]. 
... accessibility relations, the evolution of preexisting rural subdivision and/or urban and infrastructure conditions vary according to the ease or difficulty of access to the road. The highway has good specifications; also borders the land supply favoring who is best served by the transport potential. (p. 51)

\subsection{Transportation relation between Bogota and Soacha}

The municipality of Soacha, located $10 \mathrm{~km}$ south of Bogotá, is considered as a low-income city, due mainly to its characteristics of low-wage jobs. A large number of industries that require unskilled workers are found in the municipality. Even so, there are a large number of workers who live in Soacha and work in the capital.

The importance of the capital in education and in generating employment for the residents of Soacha is undeniable, and therefore daily commute to and from the capital city is high and also constant, as mentioned by Alfonso [13]: 'The importance of daily commuting from Soacha is undeniable. By themselves, these movements explain the $46.8 \%$ of daily commuting of the entire metropolitan area of Bogotá and 51.3\% of labor mobility' (p. 15).

Since the population of Soacha mainly consists of low-income workers, social inequalities lead to mobility inequalities $[14,15]$, especially in an urban context. Social inequality is concentrated mainly in those who do not have access to modes of transport in the same way as other social groups [16].

Improving the supply and quality of the city's public transport in outlying areas with scarce transport combined with land planning policies are key issues for achieving greater accessibility in the poorest population, which is defined by Burns [17, p. 42] as 'an individual characteristic in relation to the degree of optionality that different citizens can access to places and activities'. Implementing measures in their favour can reduce vulnerability and segregation of the poorer section of society. Not only is it necessary to have an empirical observation of the present and future of the population to understand the impacts of a social phenomenon in particular, it is necessary to also take into account the potential movements in people's mobility [18].

However, simply providing people located in the periphery with efficient and effective public transport does not necessarily lead to an improvement in their social level. Nevertheless, a lack of public transport does constitute a social disadvantage [19], and for this reason, public transport and cycling can in a certain way help people to have more and better mobility and accessibility in these remote city areas.

\subsection{TransMilenio and cycling in Bogota}

In Bogotá, the TransMilenio system was planned in order to improve the quality and security of public transport, and allowed in practice a reduction in travel time and an increase in accessibility to all inhabitants of the city, mainly to citizens of lower income levels, helping to ensure the right to the city expressed as the right of all citizens to enjoy different and diverse opportunities available in urban areas [20]. But in many cases, the system is a 'carrier of general values but also of public policy guidelines and technical elections' [21].

Transport has always been a problem in remote areas, and Bogotá created a new transport system based on the system of Curitiba, Brazil. Many studies have been conducted to show how this type of transport increases land price in areas near the TransMilenio [22-25] but there are still no concrete data. What has been confirmed is that for the vast majority of households, TransMilenio has been an integrating element since it has reduced travel time for 
populations located in the periphery. The 'feeder' buses (alimentadores) have also allowed for the integration of families and inhabitants that live far away from the main bus lines.

Also, during the construction and implementation of the TransMilenio, bike paths were built alongside the trunk lines, as well as throughout different zones of the city, thus providing a wider range of the population access to many destinations in the city. To date, more than $350 \mathrm{~km}$ of bike paths have been constructed in the city.

It is important to think how mobility becomes an important tool against social exclusion [26], and in 2013, with the extension of TransMilenio to Soacha, a larger population made use of the service. To really understand a population's mobility, it is important to know the urban structure on which it develops [2]. In the case of Soacha, 'Transmilenio initially embodied the hope of finally being intervened with infrastructure works in order to conceive this territory as a Municipality and not only as the exit of Bogotá by the South' [12, p. 137]. Likewise, being able to generate a mobility analysis on low-income sectors allows to explore new ways of addressing urban problems in general and urban transport and poverty in particular [27].

There are residential zones in Bogota where travel time has increased and some public transport routes have been removed because of the TransMilenio, which means that these users have to search for other means of transport or even have to make connections, which in practice represents a higher transport cost [3]. As mentioned by the Comisión Económica para América Latina y el Caribe (CEPAL) [28], 'the BRT does not represent by itself an obvious way of a favorable infrastructure development for the poor' (p. 6).

In addition, road and public transport connection between Bogotá, Soacha and many neighbourhoods in the southern periphery is not the best, increasing the travel time. It is to be mentioned that households in Soacha prefer living in the capital city, which offers recreation, work and education, even when the land price is more expensive in Bogotá [25]. People prefer living in Bogota due to the facilities and services it offers, but the reality is that, because of the land prices, many of the people had to move outside Bogota. Other reason is that they moved to Ciudad Verde sacrificing time and money to become proprietary (a total of 42,000 households and an estimated 160,000 inhabitants).

The initiative from both mayors (Bogotá and Soacha) for the extension of the TransMilenio system started in 2000, a project that was well received by the population since they thought that it would solve all mobility problems in Soacha, reducing travel time and improving quality of life, public space and public transport quality [12], including Ciudad Verde inhabitants.

It is well known that the Ciudad Verde project faced a lot of delays as mentioned by Hurtado et al. [12]: repeated change of mayors in Soacha affecting the course of the project, also restraints from the Soacha City Council that delayed the approval of future monetary aid when they did not support the mayor, inconvenience with the concessionary of the Bogotá-Girardot highway as this was a national highway but had shared infrastructure with TransMilenio and absence of a national policy. It was not until 2007 that the works finally started.

It might be possible that TransMilenio in Soacha, in its current phase, has not helped the community in general but only those who live relatively close to the new infrastructure. The inhabitants of Soacha could benefit from a TransMilenio that is integrated with other modes of transport. Unfortunately, of the four stations that are operating today, none has access or parking facilities for bicycles. This integration could help potential users arrive by bicycle to the stations and use the TransMilenio to finish their journey, as for example in Portal Américas in Bogotá.

Despite all the inconveniences, finally in 2013, Phase 1 (of three phases planned) of TransMilenio in Soacha started operating with only four stations. However, the 'feeder' bus system 
will not start operating until 2016, which implies that inhabitants in Soacha have to take other means of transport to reach the stations, incurring additional costs.

Currently, the BRT system has problems due to congestion generated in stations. Demand was initially projected at 45,000 passengers/day, but this was far exceeded as more than 70,000 passengers/day began to use the four stations. This has led to the TransMilenio to widen some stations and reorganize the routes.

\section{RESULTS}

The TransMilenio has become a transit system that has helped the community, especially the inhabitants located in the periphery, and who in many cases did not have any access to formal public transport because according to Lungo [29, p. 266], 'the provision of adequate public transport systems could play a central role to improve the quality of life of the growing Latin American cities'. Bicycling could enhance access to TransMilenio for those residents living beyond easy walking distance or without access to either adequate feeder transit or cars.

Regarding Bogotá, according to the Law Agreement 348 of 2008, the city has planned a bicycle sharing system - BiciBog - but unfortunately it is yet to start operations. Between 4 and 18 November 2011, a pilot project took place in two areas of the city: one in a highincome neighbourhood (Virrey) and the other in a southern peripheral area (Portal Américas). In this pilot project, bicycle stations were located next to TransMilenio stations, so that bicycles could serve as 'feeders' into the main TransMilenio system (see Fig. 3). These kinds of proposals are positive because the implementation process of BiciBog has started and this gives many possibilities to continue with these initiatives [30]. In general, the pilot project was perceived as very positive. Users in both Portal Américas and Virrey generally provided favourable feedback regarding the pilot project, while expressing concerns with bike access to roads and paths as well as the quality of the bicycles themselves.

On the other hand, 100 quantitative research surveys were conducted at the Restrepo TransMilenio station in a low-income neighbourhood south of the city, to learn more of perceptions regarding bicycle (private or public) use for arriving at the TransMilenio station (assuming adequate bike parking). The intention was to 'see what richness they contain and what insights they might reveal' [31, p. 51] without intending to find a representative statistic. Also, in contrast, the data of the Mobility Survey (EMU 2011 [10]) were analysed in order to understand bicycle use in the periphery near the Portal Américas and Portal Sur BRT terminal stations.

The questions were intended to identify whether people would be likely to use their bicycle or a public bicycle system. This type of bicycle sharing programme has been introduced all over the world as part of urban transportation policies in order to extend the accessibility of public transportation systems to their final destinations [32]. Table 1 shows the perception towards the use of bicycles assuming they were able to park them, or if a bicycle sharing system were to exist. More than $80 \%$ of the interviewees are daily users of the TransMilenio and arrive at the station walking, the other $20 \%$ are also users of TransMilenio but they use other means to arrive at the station such as taking a taxi or public bus.

Table 1: Results of the questions made to TransMilenio users regarding the use of bicycle.

\begin{tabular}{lcc}
\hline Question & Yes $(\%)$ & No $(\%)$ \\
\hline $\begin{array}{l}\text { Would you make this same trip on your own } \\
\text { bicycle? }\end{array}$ & 52.5 & 47.5 \\
$\begin{array}{l}\text { Would you make this same trip on a public } \\
\text { bicycle? }\end{array}$ & 51.5 & 48.5 \\
\hline
\end{tabular}




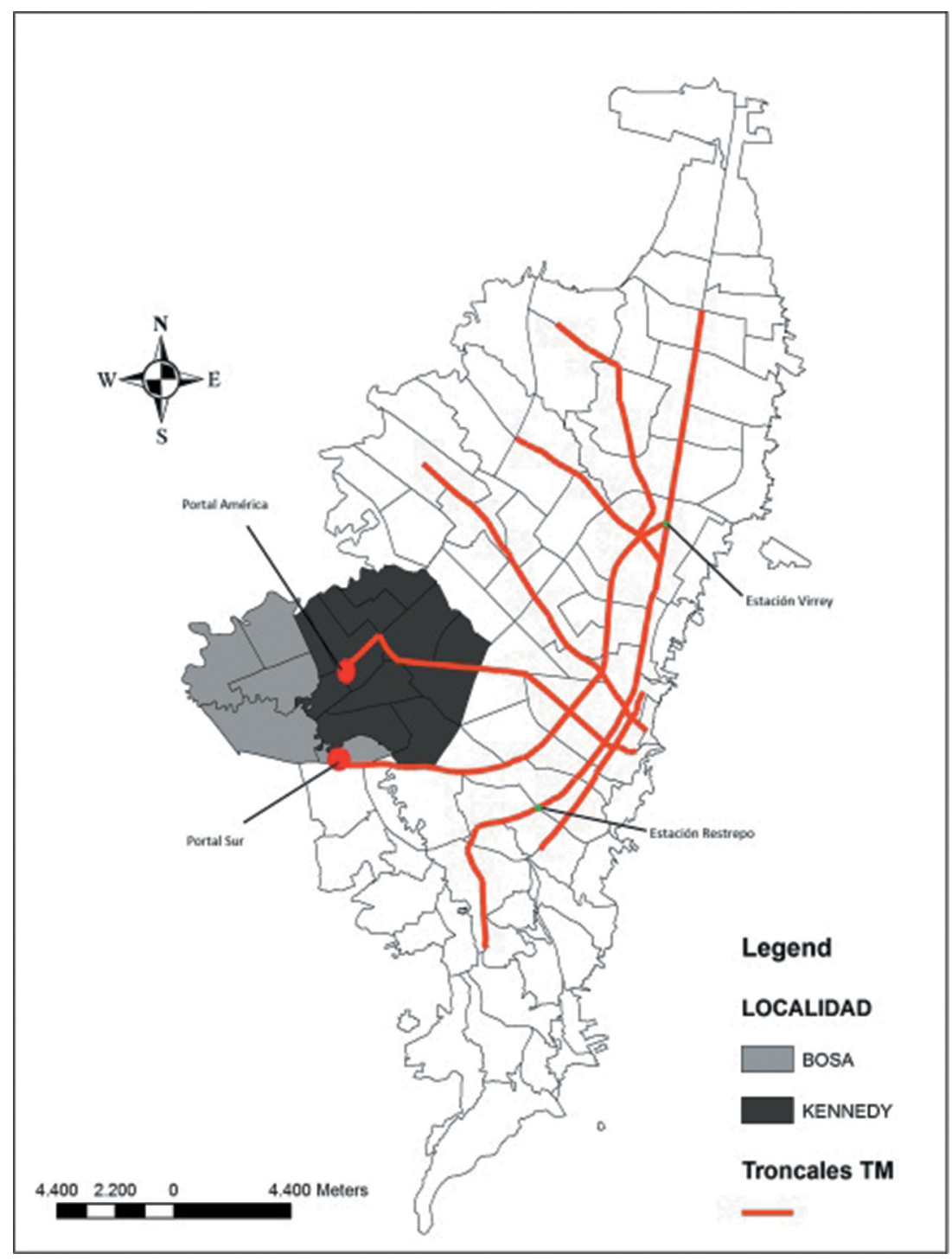

Figure 3: Portal Américas and Portal Sur.

From the answers, we can perceive that even if people were to have access to a public or private bicycle and a space to park it, more than half of the people will not use a bicycle to reach the station. This could be due to the lack of bike paths to reach the station, security issues, lack of information of what a bicycle sharing system is, among other reasons.

Contrasting the results of the pilot project (well received and public interest), we can assume that the results of the survey made in Restrepo conflicted with results from the pilot project, perhaps because people in Américas and Virrey were able to actually use the bicycle and feel the benefits of using it. This should be studied in a much more detailed manner in order to have concise results and data to support the argument since at present, there is 
limited research on the environmental and social benefits of bikesharing [33]. Nevertheless, we can assume that there will be an increased use of bicycles which can serve as a feeder to the system.

With the TransMilenio, big investments in pedestrian and bike paths were also made "in form of "green connectors" (...) [which] connects some of the poorest barrios and informal housing settlements (with highly trans-dependent populations) to the busways' [34]. However, using only a supply-driven policy is not enough to increase cycling levels [35]. Even though these green connectors, located mainly in the peripheral TransMilenio portals, were of great help, the trips made by bicycle to the TransMilenio in the periphery, according to the EMU, are almost nil.

Nevertheless, despite the integration between bicycle and TransMilenio being very low (reaching about $0.3 \%$ of the total trips) at a statistical level, the bike parking facilities built to promote the integration of cycling and TransMilenio show a remarkable level of occupation. This indicates potential for growth of bicycle use to reach TransMilenio 'since as a feedering mode, the bicycle is substantially faster than walking and more flexible than public transport' [36, p. 282] and can bring more users into the system.

\section{RECOMMENDATIONS AND CONCLUSIONS}

There have been some areas in the periphery in which commuting time has increased. But we can say that in general, the operation of the TransMilenio has brought more benefits than drawbacks to the population, allowing them to improve their travel times and giving them the opportunity to invest this time in other aspects of their life, such as family.

With the TransMilenio, some old routes have gone out of operation. This had repercussions on those people who used this traditional service to commute. Now, with these routes out of service, people have to rearrange their commuting plans, having to take more than one bus because they cannot make use of the TransMilenio to reach their destination or they have to change to the bicycle for reaching the stations.

Until a few years ago, urban management was conducted by the municipality. Today, with urban issues no longer belonging only within local jurisdictional limits, it is necessary to create mechanisms for managing the metropolitan topics, for example those related to transport. As has been demonstrated in this article, there has been a lack of authority to manage the problematic development of the TransMilenio extension, since there were local interests in each of the municipalities (Bogotá and Soacha) as well as departmental and national interests. So, if there were to have been a metropolitan authority, these kinds of mishaps would not have occurred.

It is true that TransMilenio has taken the first steps towards a better integration of the peripheral neighbourhoods, reaching places where previously there was no public transport, and providing opportunities to allow access to goods and services offered to the citizens in the capital city. But unfortunately it has still not fully and efficiently reached all places.

Bicycling can help bring people living in the periphery to the city by improving access to the TransMilenio system, thus reducing social and spatial segregation and giving these people the possibility of a better quality of life. It has been proven that people do use a bicycle sharing system to make both their ingress and egress trips, so there is the necessity for the city to commit to carrying forward the bicycle sharing system, jointly with the proposal of the first Metro line in the city and continue with the promotion and construction of new bicycle paths and parking facilities.

It is not enough to give the poor citizens good quality apartments, with good facilities (green areas, parks, among others). It is also essential to think about how they are going to commute (public transport), where will they go if they get sick (hospitals), who will they 
call for security issues (police headquarters) or where will they take their children for education (schools). It is important to make the government take ownership of the project and really think about people's needs, and mobility in particular is one factor that has yet to be adequately addressed in the fight against segregation.

\section{REFERENCES}

[1] Dureau, F., Las nuevas escalas de la segregación en Bogotá. Metrópolis en movimiento. Alfaomega: Bogotá, Colombia, pp. 162-170, 2002.

[2] Avellaneda, P., Movilidad, pobreza y exclusión. Un estudio de caso en la ciudad de Lima, 2007, available at http://www.tesisenxarxa.net/TDX/TDX_UAB/TESIS/AVAILABLE/ TDX-1005107-161727//pag1de1.pdf

[3] Salas, A., Segregación residencial y producción de vivienda en Bogotá, entre imágenes y realidades. PhD Thesis, Université de Poitiers UFR de Sciences Humaines et Arts, Département de Géographie, France, 2008.

[4] Garretón, M., Desigualdad espacial y utilidad social: esfuerzos de movilidad y accesibilidad en el Gran Santiago. Territorios, 25, pp. 35-64, 2011.

[5] Vittadini, M., La citta accessibile. in Tempi di vita. Studi e proposte per cambiarli. Feltrinelli. Italia, 1991.

[6] Thynell, M., Social change and urban transport. Sustainable urban transport technical document \# 2. GTZ; Eschborne, Germany, 2009.

[7] Jirón, P., Lange, C. \& Bertrand, M., Exclusión y desigualdad espacial: retrato desde la movilidad cotidiana. Revista INVI, 68(25), pp. 15-57, 2012.

[8] Dureau, F., Barbary, O., Gouëset, V., Pissoat, O. \& Lulle, T. (eds), Ciudades y sociedades en mutación. Lecturas cruzadas sobre Colombia, Universidad Externado de Colombia: Bogotá, 2007.

[9] Cortés, R., Evaluación y criterios de manejo de los inventarios de zonas subnormales. Manejo cualitativo de los datos sobre una muestra de 10 ciudades. Inurbe, Bogotá, 1993.

[10] Secretaría de Movilidad de Bogotá. Encuesta de Movilidad Urbana, Alcaldía Distrital de Bogotá, 2011.

[11] Orellana, A., La evolución y la configuración de la calidad de vida en Chile en el contexto de regiones urbanas. Work presented in the Seminario; De la ciudad a la región, RIDEAL, Medellín, 2013.

[12] Hurtado, A., Hernández, M. \& Miranda, L., Gestión de grandes proyectos urbanos en espacios metropolizados: los sistemas integrados de transporte masivo en Colombia. Universidad Piloto de Colombia, 2014.

[13] Alfonso, O., Profundización de las relaciones de metropolización de Bogotá con la Sabana, VIII Seminario de Investigación Urbana y Regional ACIUR, 2009, available at http://institutodeestudiosurbanos.info/dmdocuments/Profundizacion_Relaciones_ Metropolizacion_Bogota-Alfonso_Oscar-Documento.pdf

[14] de Vasconcellos, E., Urban transport, environment, and equity: the case for developing countries. Earthscan: London, 2001.

[15] Figueroa, O., Transporte urbano y globalización. Políticas y efectos en América Latina. Eure, 94(31), pp. 41-53, 2005. DOI: 10.4067/S0250-71612005009400003.

[16] Ureta, S., To move or not to move? Social exclusion, accessibility and daily mobility among the low-income population in Santiago, Chile. Mobilities, 3(2), pp. 269-289, 2008.

[17] Miralles-Guasch, C., Ciudad y transporte. El binomio imperfecto. Ariel Geografía: Barcelona, Spain, 2002. 
[18] Kaufman, V., Motility: a key nation to analyse the social structure of second modernity? Available at http://mobilitypioneers.de/Dokumente/download/Statement-Kaufmannfrei.pdf

[19] Brand, P., El significado social de la movilidad (Chapter 1). Movilidad urbana y pobreza. Aprendizajes de Medellín y Soacha, Colombia, ed. J. Dávila, UCL y Universidad Nacional de Colombia: Bogotá, Colombia, pp. 16-23, 2012.

[20] Lefèbvre, H., El derecho a la ciudad. Ed Anthropos: Paris, 1968.

[21] Jouffe, Y. \& Lazo, A., Las prácticas cotidianas frente a los dispositivos de la movilidad. Aproximaciónpolítica a la movilidad cotidiana de las poblaciones pobres periurbanas de Santiago de Chile. EURE, 36(108), pp. 29-47, 2010. DOI: 10.4067/ S0250-71612010000200002.

[22] Targa, F., Examining Accessibility and Proximity-Related Effects of Bogotá's Bus Rapid System Using Spatial Hedonic Price Models. University of North Carolina: Chapel Hill, 2003.

[23] Perdomo, J., Una propuesta metodológica para estimar los cambios sobre el valor de la propiedad: estudio de caso para Bogotá aplicando Propensity Score Matching y Precios Hedónicos Espaciales. Lecturas de Economía, 73, pp. 49-65, 2010.

[24] Rodríguez, D. \& Mojica, C., Capitalization of BRT network expansions effects into prices of non-expansion areas. Transportation Research Part A: Policy and Practice, 43(5), pp. 560-571, 2009. DOI: 10.1016/j.tra.2009.02.003.

[25] Bocarejo, J.P., Portilla, I. \& Pérez, M.A., Impact of Transmilenio on density, land use, and land value in Bogotá. Research in Transportation Economics, 40(1), pp. 78-86, 2013. DOI: 10.1016/j.retrec.2012.06.030.

[26] Cámara de Comercio de Bogotá. Observatorio de movilidad de Bogotá y la región: caracterización e indicadores de la movilidad en Bogotá. Bogotá, 2007.

[27] Montezuma, R., Transformación urbana y movilidad: contribución al debate en América Latina. Working paper, Programa de gestión urbana, Coordinación para América Latina y el Caribe, Quito, Ecuador, 2003.

[28] Comisión Económica para América Latina y el Caribe (CEPAL). El transporte, la pobreza y el avance hacia sociedades con bajas emisiones de carbono. Boletín FAL, 318(2), 2013.

[29] Lungo, M., Expansión urbana y la regulación del uso del suelo en América Latina. Uso del suelo y desarrollo urbano (Chapter 5). Perspectivas urbanas. Temas críticos en políticas del suelo en América Latina, eds. M. Smolka \& L. Mullahy, Lincoln Institute of Land Policy: Cambridge, MA, pp. 265-333, 2001.

[30] Pardo, C. \& Moreno, C., Recomendaciones al sistema BiciBog (piloto). ITDP \& Despacio, Bogotá, Colombia, 2011.

[31] Chandler, J., Academics as professionals or managers? A textual analysis of interview data. Qualitative Research in Accounting \& Management, 5(1), pp. 48-63, 2008. DOI: 10.1108/11766090810856778.

[32] Lin, J.-R. \& Yang, T.-H., Strategic design of public bicycle sharing systems with service level constraints. Transportation Research Part E, 47, pp. 284-294, 2011. DOI: $10.1016 /$ j.tre.2010.09.004.

[33] Shaheen, S., Guzman, S. \& Zhang, H., Bikesharing in Europe, the Americas, and Asia: past, present and future. Journal of the Transportation Research Board, 2143, pp. 159-167, 2010. 
[34] Cervero, R., Public Transport and Sustainable Urbanism: Global Lesson. Science Council of Japan, 2006.

[35] Nkurunziza, A., Zuidgeest, M., Brussel, M. \& van Maarseveen, M., Examining the potential for modal change: Motivators and barriers for bicycle commuting in Dar-esSalaam. Transport Policy, 24, pp. 249-259, 2012. DOI: 10.1016/j.tranpol.2012.09.002.

[36] Martens, K., The bicycle as a feeding mode: Experiences from three European countries. Transportation Research Part D: Transport and Environment, 9(4), pp. 281-294, 2004. DOI: $10.1016 / j . t r d .2004 .02 .005$. 